Note

\section{Composition and Properties of Mucilage Excreted by Euglena gracilis $\mathrm{Z}$}

\section{Yoshiyuki Tamura,* Kazutaka Miyatake and Shozaburo KITAOKA}

\author{
* College of Hagoromogakuen, Takaishi, Osaka 592, \\ and Department of Agricultural Chemistry, \\ University of Osaka Prefecture, \\ Sakai, Osaka 591, Japan
}

Received January 24, 1986

Euglenoids excrete mucilage depending on the culture conditions. ${ }^{1)}$ Euglena mucilage is a very insoluble material, and its composition and properties are not well known. ${ }^{2,3)}$ In this paper we report the solubilization, composition, and chemical properties of the mucilage from Euglena gracilis $\mathbf{Z}$.

A streptomycin-bleached mutant from E. gracilis $\mathrm{Z}$ produced much more mucilage than did the wild type cells. The bleached mutant was cultured in Koren-Hutner medium $^{4)}$ in the dark at $27^{\circ} \mathrm{C}$ for 5 days with shaking (90 strokes/min), and cells with mucilaginous substance were collected by centrifugation $(1000 \times g, 5 \mathrm{~min})$. They were suspended in distilled water and centrifuged at $600 \times g$ for 5 min to separate the mucilage from the cells. This procedure was repeated several times to remove the cells completely from the mucilage fraction, and then the mucilage was washed with $6 \mathrm{M}$ urea solution to remove soluble materials. The purity of the mucilage was checked under an optical microscope. After rinsing with acetone and ether, the mucilage was dried under reduced pressure at room temperature. The mucilage preparation thus obtained contained $4.2 \%$ water.

The Euglena mucilage was not soluble in many inorganic and organic solvents. However, we found that it was solubilized in anhydrous formic acid at $25^{\circ} \mathrm{C}$ and the maximal solubility of the mucilage was $35 \mathrm{mg}$ (anhydrous weight) $/ \mathrm{ml}$ of anhydrous formic acid at $25^{\circ} \mathrm{C}$. The contents of sugar and amino acids are given as the anhydrous form of mucilage unless otherwise specified. The carbohydrate content of the solubilized mucilage was examined with the anthrone, ${ }^{5)}$ phenol-sulfuric acid, ${ }^{6)}$ and orcinol-sulfuric acid methods, ${ }^{7)}$ using D-glucose as a standard. The content was $75.2 \%$ by the anthrone, $89.4 \%$ by the phenol-sulfuric acid, and $90.4 \%$ by the orcinol-sulfuric acid methods. Sialic acid was not detected by the resorcinol method. ${ }^{8)}$ The mucilage $(1 \sim 1.5 \mathrm{mg})$ was suspended in $100 \mu \mathrm{l}$ of $60 \%$ sulfuric acid at room temperature in a small glass tube $(1 \times 7 \mathrm{~cm})$ and the suspension was diluted with $1 \mathrm{ml}$ of water. The mucilage was hydrolyzed in vacuo for $12 \mathrm{hr}$ at $100^{\circ} \mathrm{C}$, and the hydrolysate was neutralized with barium carbonate. After centrifugation the supernatant was evaporated to a small volume and passed through Dowex$50 \times 8(0.3 \mathrm{ml}, \mathrm{H}$ form $)$ to remove barium ion. The resin was washed with $0.7 \mathrm{ml}$ of water. The effluent was evaporated to dryness and the residue repeatedly evaporated with added methanol. GLC analysis of the trimethylsilyl (TMS) derivatives of sugars was done as follows: to the above dried hydrolysate was added $100 \mu \mathrm{g}$ of Ddeoxyglucose as an internal standard. The mixture was evaporated to dryness, dehydrated over $\mathrm{P}_{2} \mathrm{O}_{5}$ in vacuo, and converted to TMS-derivatives with $0.5 \mathrm{ml}$ of TMS reagent (pyridine-hexamethyldisilazane-trimethylchlorosilane $=10: 2: 1, \mathrm{v} / \mathrm{v}$ ) at $37^{\circ} \mathrm{C}$ for $60 \mathrm{~min}$. GLC was done with a Shimadzu Gas Chromatograph model 7A, with a hydrogen flame ionization detector, using a column of $5 \%$ SE-30 on Chromosorb (60 80 mesh) at $170^{\circ} \mathrm{C}$. Analysis of the mucilage preparation by GLC showed the presence of glucose, fucose, arabinose, and small amount of unidentified sugars. The molar ratio of glucose, fucose, and arabinose was $89: 8: 3$; the mucilage from $E$. glacilis $\mathrm{Z}$, a wild strian, gave the same result. The mucilage preparation from E. gracilis var. bacillaris has been reported to contain at least $82 \%$ carbohydrate, and its chromatographic analysis has shown the presence of glucose, galactose, mannose, xylose, fucose, rhamnose, and small amounts of unidentified sugars. ${ }^{2)}$ The reason for the difference in the sugar composition between the two strains of E. gracilis is not known. The amino acid composition of the acid hydrolysate showed the presence of glucosamine (see Table I) and its content was very small, compared with those of other sugars. Phosphoric acid was not detected in this mucilage by the method in the Official Methods of Analysis of AOAC. ${ }^{9)}$

The nitrogen content of the mucilage preparation was $1.97 \%$ from elemental analysis and $1.8 \%$ from semimicroKjeldahl analysis, indicating that $10 \sim 12 \%$ of protein is contained in the Euglena mucilage. The amino acid content was measured by the ninhydrin reaction of acid $(5.7 \mathrm{~N} \mathrm{HCl}$ at $110^{\circ} \mathrm{C}$ for $\left.22 \mathrm{hr}\right)$ and alkaline $\left(2.5 \mathrm{~N} \mathrm{NaOH}\right.$ at $100^{\circ} \mathrm{C}$ for $2 \mathrm{hr}$ ) hydrolysates using L-lelucine as a standard. The content was $14 \%$ by the former and $12 \%$ by the latter methods. The amino acid composition of the mucilage is shown in Table I. The mucilage is secreted from a subpellicular structure termed muciferous body, ${ }^{3)}$ but the amino acid composition of the mucilage is evidently different from that of the pellicle. ${ }^{2)}$ The contents of serine, glutamic acid, and alnine were high, and cystine residues are present in contrast to a report on the pellicle ${ }^{2)}$ (Table I). These results suggest that the mucilage is a glycoprotein composed of about $10 \sim 15 \%$ of protein and $85 \sim 90 \%$ of carbohydrate. The amino acid composition of the solid mucilage was similar to that of the preparation solubilized in anhydrous formic acid, indicating that the mucilage is solubilized with no critical variation in composition. 

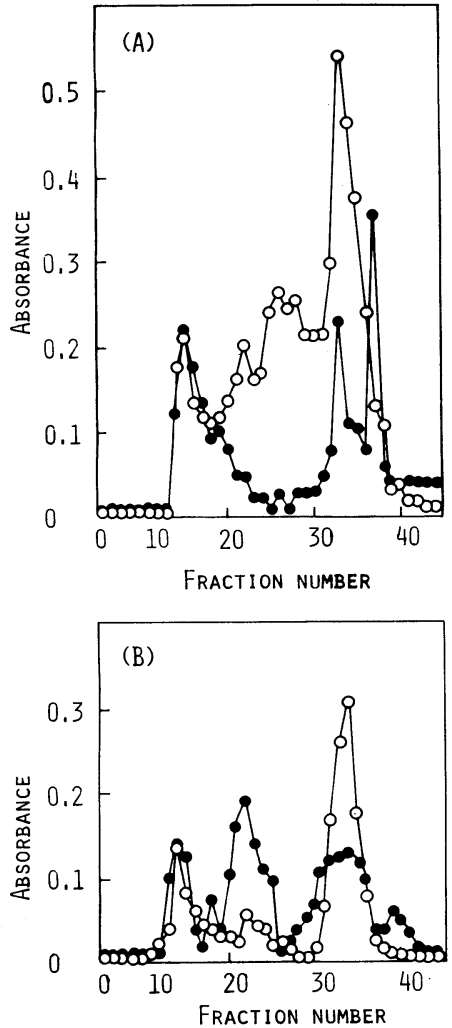

FIG. 1. Gel Filtration Chromatographies of Mucilage Preparations Hydrolyzed with Cellulysin (A) and Laminarinase (B) on Sephadex G-50.

(A) The mucilage preparation $(10 \mathrm{mg})$ was suspended in $2 \mathrm{ml}$ of $0.1 \mathrm{M}$ acetate buffer, $\mathrm{pH} 5.0$. Cellulysin $(1.5 \mathrm{mg})$ was added at the beginning of digestion and the digestion was continued at $25^{\circ} \mathrm{C}$ for $48 \mathrm{hr}$. The soluble fraction was filtered on Sephadex G-50 Gel $(2.0 \times 46 \mathrm{~cm})$ equilibrated with $0.1 \mathrm{M}$ acetate buffer, $\mathrm{pH} 5.0$.

(B) The mucilage preparation $(10 \mathrm{mg})$ was suspended in $2 \mathrm{ml}$ of $0.1 \mathrm{M}$ acetate buffer, $\mathrm{pH}$ 5.0. Laminarinase $(1.5 \mathrm{mg}$ ) was added at the beginning of the digestion and the digestion was continued at $20^{\circ} \mathrm{C}$ for $72 \mathrm{hr}$. The soluble fraction was filtered on the same size of Sephadex column. $\bigcirc-\bigcirc$, absorbance at $490 \mathrm{~nm}$ measured with phenolsulfuric acid method; - absorbance at $570 \mathrm{~nm}$ measured with ninhydrin reaction after alkaline hydrolysis in $2.5 \mathrm{~N} \mathrm{NaOH}$ at $100^{\circ} \mathrm{C}$ for $2 \mathrm{hr}$. Each fraction volume was $2.9 \mathrm{ml}$.

The mucilage preparation was enzymatically hydrolyzed by cellulysin (EC 3.2.1.4., 1,4-(1,3:1,4)- $\beta$-D-glucan 4glucanohydrolase) (Type $\mathrm{V}$, from Trichoderma viride, Sigma) and laminarinase (EC 3.2.1.6., 1,3-(1,3:1,4)- $\beta$-Dglucan 3(4)-glucanohydrolase, from Mollusk, Sigma). The mucilage was suspended in $2 \mathrm{ml}$ of $0.1 \mathrm{M}$ acetate buffer, $\mathrm{pH}$ 5.0 , and digested with cellulysin $1.5 \mathrm{mg}$ ) at $25^{\circ} \mathrm{C}$ for $48 \mathrm{hr}$ or laminarinase $(1.5 \mathrm{mg})$ at $20^{\circ} \mathrm{C}$ for $72 \mathrm{hr}$. The carbohy-
Table I. Comparison of Amino Acid Composition of Mucilage and Pellicle from Euglena

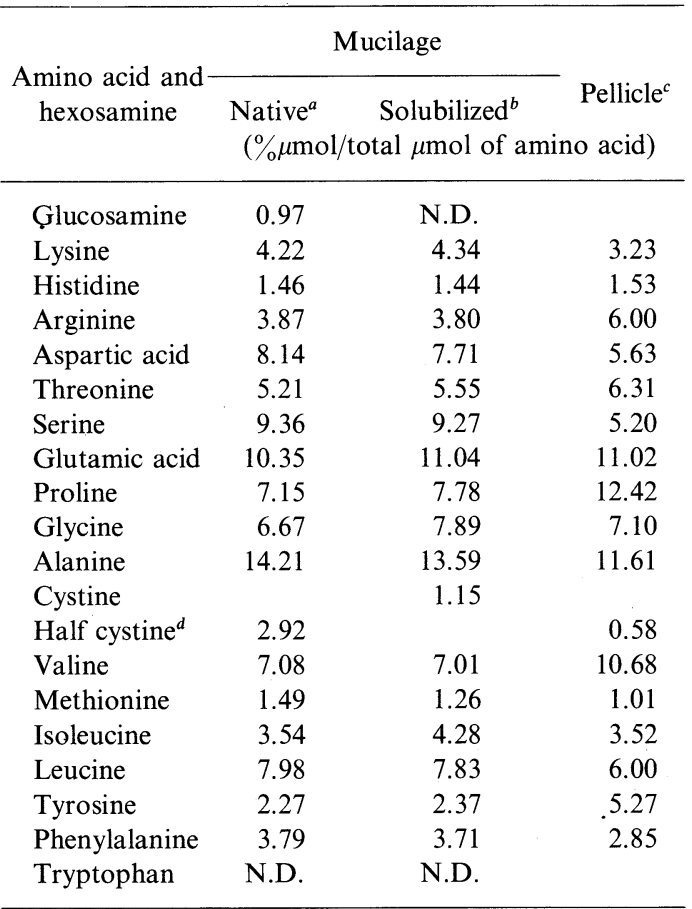

a Solid mucilage preparation was directly hydrolyzed at $110^{\circ} \mathrm{C}$ for $22 \mathrm{hr}$ in $5.7 \mathrm{~N} \mathrm{HCl}$.

$b$ Mucilage preparation which was solubilized in anhydrous formic acid was hydrolyzed at $110^{\circ} \mathrm{C}$ for $22 \mathrm{hr}$ in $5.7 \mathrm{~N} \mathrm{HCl}$.

c Barras and Stone. ${ }^{2)}$

d Measured as cysteic acid by the performic acid oxidation method. N.D. = not determined. Amino acid analysis was done with a Hitachi Amino Acid Analyzer (Model KAL-5).

drate portion of the mucilage was hydrolyzed by $36 \%$ by the former and by $23 \%$ by the latter enzymes as measured by the phenol-sulfuric acid method, $\left.{ }^{6}\right)$ suggesting that the polysaccharide in the mucilage has $\beta$-1,4- or $\beta$-1,3-linkages or both. After centrifugation of the digested preparation, the supernatants were filtered on Sephadex G-50 gel. The elution profiles are shown in Fig. 1; the enzymatic hydrolysates were thus fractionated to some carbohydrate fraction with different molecular weights. The elution patterns showed that cellulysin (profile A) hydrolyzed the polysaccharides of the mucilage more extensively than laminarinase (profile B). The amino acid analysis of these carbohydrate fractions showed that all of them contained the peptide portions.

\section{REFERENCES}

1) A. Diskus, Protoplasma, 45, 460 (1956). 
2) D. R. Barras and B. A. Stone, Biochem. J., 97, 14P (1965)

3) D. R. Barras and B. A. Stone, "The Biology of Euglena," Vol. 2, ed. by D. E. Buetow, Academic Press, New York, 1968, p. 159.

4) L. E. Koren and S. H. Hutner, J. Protozool., 14, Suppl. 17 (1967).

5) R. Drywood, Ind. Eng. Chem. Anal. Ed., 8, 499 (1946).
6) M: Dubois, K. A. Gilles, J. K. Hamilton, P. A. Rebers and F. F. Smith, Anal. Chem., 28, 350 (1956).

7) C. Francois, R. D. Mareshall and A. Neuberger, Biochem. J., 83, 335.(1962).

8) L. Svennerholm, "Methods in Enzymol.," Vol. 6, ed. by S. P. Colowick and N. O. Kaplan, Academic Press, New York, 1963, p. 459.

9) "Official Methods of AOAC," 8th Ed., 1955, p. 115. 